\title{
ЗА ГРЕВОТ, ТИШИНАТА И ДРУГОСТА
}

Трансиендентално читање на Кјеркегоровото учење за прародителскиот грев

\section{Кратка содржина}

Овој труд ке се обиде да ја испита врската помеѓ гревот и тишината од една страна и гревот и светот, или другоста од друга, преку разгледување на Кјеркегеровото учење за гревот - а поточно, за првиот грев на Адам - онакво какво ито е претставено во неговиот Поим за тегобноста. Тој има три мегусебно поврзани чели. Првата е да укаже на тоа дека ова дело поставува една оригинална идеалистичко-трансиендентална епистемолочка рамка. Втората, е да покаже дека остварувањето на гревот на Адам изискува извесен говор, односно, еден вид на разговор на човекот со самиот себе; но и дека тоа случува надвор од каков било однос со другиот. Имено, ваквиот грев за прв пат востановува некаква другост. Конечно, третата е да утврди, врз основа на некои од заклучочите од претходно изложеното, дека вбројувањето на прародителскиот грев во етичките поими, неговото обележување како добар или како зол, треба, во најмала рака, да се земе сит grano salis.

КЛучни зборови: КЈЕРКЕГОР, ТЕГОБНОСТ, ПРАРОДИТЕЛСКИ ГРЕВ

"Le scandale du monde est ce qui fait l'offense; Et ce n'est pas pécher que pécher en silence." Molière $^{1}$

Овие сега веќе славни зборови се оние кои, меѓу другото, Молиер ги става во устата на својот Тартиф, лицемерен богоугодник кој сака да се натрапи во куќата на лековерниот Оргон - не, согласно желбата на овој, како надежен домазет, а заведувајќ ја неговата сопруга, како иден господар. „Ни следува суд за она што е знајно, а грев не е она што се врши тајно!“2, вели македонскиот препев и ја подава, онолку колку и што може да се очекува од него, смислата на даденото слово. И се разбира, имајќи ги предвид околностите во кои е искажана како и нејзината содржина, една ваква изјава бездруго ќе се сретне со неодобрување од страна на оној кој ја восприема. Па и покрај ова, доколку овие околности се изземат а човек се задржи на подробностите на изворната француска реч, таа би можела, покрај предметот за осуда, да понуди и предмет за расудување.

Имено, во ова кусо обраќање, Тартиф успева да каже две различни, а поврзани нешта за гревот: прво, дека грешењето во тишина не е грешење и второ,

\footnotetext{
${ }^{1}$ Molière, Le Tartuffe ou l'imposteur, Paris : Hachette, 1992, p. 117

${ }^{2}$ Молиер, Тартиф, прев. Лазо Каровски, Скопје: Детска Радост, 1996, с. 154
} 
дека прекршокот во кој се состои гревот не е ништо друго од реакцијата на „светот“, неговото „скандализирање“. Секако, ова е доста посуптилно од простото вообразување дека едно дејство не е грев доколку се премолчи, не само поради тоа

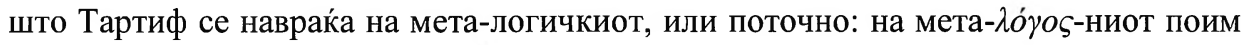

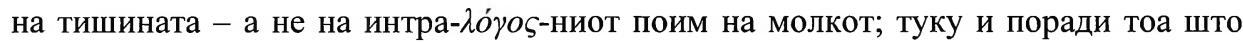
преку „скандалот“ тој воспоставува тесна врска меѓу прекршокот и „светот“, поточно другоста, вклучително и онаа на другиот човек. Впрочем, старогрчкото $\sigma \kappa \alpha ́ v \delta \alpha \lambda o v$ - кое, барем што се однесува до Новиот Завет, на македонски најчесто се подава со „соблазна“ - ги означува истовремено пречката на која некој се сопнува или поводот за неговото запаѓње во престап и оние кои, намерно или ненамерно, тој ги подметнува на патот на останатите за да ги препне ${ }^{3}$. Само во второ време тоа ја носи и денес широко распространетата смисла на она кое по нечие паѓање, се јавува како одговор од страна на набљудувачите. Одовде, излагањето на Тартиф поттикнува две одделни прашања за гревот: она за неговиот однос со феноменот на тишината и она за неговиот однос со светот, или, општо земено, другоста. Срочени во едно: дали навистина гревот е возможен во тишина, и надвор од врската со останатите и ако да, за каков грев станува збор?

Овој труд ќе се обиде да ја испита врската помеѓу гревот и тишината од една страна и гревот и светот, или другоста од друга, преку разгледување на Кјеркегеровото учење за гревот - а поточно, за прародителскиот грев на Адам - онакво какво што е претставено во неговиот Поим за тегобноста. За почеток, тој ќе укаже на тоа дека, на изненадувачки начин, ова дело поставува една оригинална идеалистичко-трансцендентална епистемолошка рамка. Потоа, тргнувајќк од неа, тој ќе се насочи на првородениот грев и на начинот на кој Адам се затекнува во него, покажувајќи дека неговото остварување изискува извесен говор, односно, еден вид на разговор на човекот со самиот себе. Дополнително, а со оглед на ова, првородениот грев ќе се открие како настан кој се случува надвор од каков било однос со другиот, без оглед на тоа за кој друг станува збор; или, што се сведува на исто, тој ќе се објави како појава која за прв пат востановува некаква другост. За крај, потпирајќи се на некои од заклучоците од претходно изложеното - како и на

\footnotetext{
${ }^{3}$ И двете вакви идеи се присутни, на пример, во Евангелието според Матеја. Така: „И како повика Исус едно дете, го постави меѓу нив и им рече: „Вистина ви велам, ако не се повратите и не бидете како деца, нема да влезете во царството небесно: кој, пак, ке се смири како ова дете, тој е поголем во царството небесно; и, кој прима такво дете во Мое име, Мене Ме

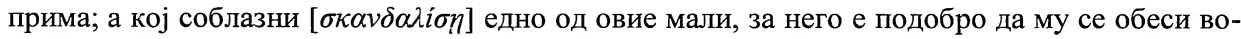
денички камен на вратот и да потоне во морска длабочина. Тешко му на светот од соблазни

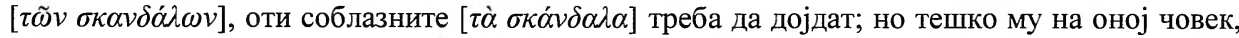

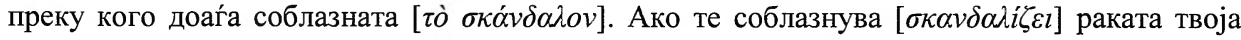
или ногата твоја, отсечи ја и фрли ја од себе: подобро е за тебе да влезеш во животот без рака или без нога, отколку со двете раце и двете нозе да бидеш фрлен во вечниот оган; и

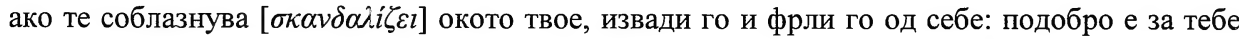
да влезеш во животот со едно око, отколку да ги имаш и двете очи, а да бидеш фрлен во геената огнена.“, Свето евангелие според Матеја, Свето Писмо (Библија), Скопје: Македонска книга, 1991, 18, 2-9.
} 
согледбата според која етиката е наука која оценува што е добро а што зло - тој ќе утврди дека вбројувањето на прародителскиот грев во етичките поими, неговото обележување како добар или како зол, треба, во најмала рака, да се земе cum grano salis.

\section{$* * *$}

Наспроти она што го кажува самиот наслов, Поимот за тегобноста не е - или барем, не е непосредно - списа која се занимава со тегобноста. Тоа е списа која се занимава со гревот, што, ако ништо друго, е видливо од тоа што се отвора со сомнежот во поглед на неговото можно објаснување во некоја гранка на човековото знаење $\mathrm{e}^{4}$ Сепак, ова не значи дека гревот е научно неподатлив, а поправо дека е, така да се рече, интердисциплинарен. Иако ниту една наука не е доволна за неговото рассветлување, три од нив - етиката, догматиката и психологијата - содејствуваат во таа насока.

Тогаш на кој начин се одвива нивната соработка? Ова прашање е дотолку потешко за одговарање што гледиштата на Кјеркегор се претставени не на вообичаениот праволиниски начин, а ,зиг-загално“5. Согласно, тие не можат да бидат едноставно пренесени, без истовремено да бидат барем делумно разместени.

Етиката, тврди уште на почетокот тој, се стреми кон тоа да го воведе идеалното во актуалното, односно, да земе дадена идеја како урнек согласно на кој треба да се дофати секој актуален отпечаток на оваа идеја, но и во однос на кој треба да се суди за ваквите нејзини единечни појави ${ }^{6}$. Но, таа се соочува и со две

${ }^{4}$ Оригиналното дело, Begrebet Angest, е достапно на: http://sks.dk/ba/txt.xml Цитатите во овој труд пак, се служат со него и со комбинација од неговите преводи на англиски јазик: Sœren Kierkegaard, The Concept of anxiety, tran. Reidar Thomte and Albert B. Anderson, Princeton: Princeton University Press, 1980; на германски јазик: Sören Kierkegaard, Der Begriff der Angst in Christoph Schrempf (hrsg.), Zur Psychologie der Sünde, der Bekehrung und des Glaubens, Leipzig: Fr Richter, 1890 и на француски јазик: Sœren Kierkegaard, Miettes philosophiques. Le concept de l'angoisse. Traité du désespoir, trad. Knud Ferlov et Jean-Jacques Gateau, Paris : Gallimard, coll. Tel, 1990. За секој извадок во белешка ќе бидат посочени трите верзии, односно, за англиската: $C A$ (en), за германската: $B A$ и за француската: $C A(f r)$.

${ }^{5}$ Според Хусерл „зиг-загалноста“ е една од методолошките одлики на феноменологијата во нејзиното својство на трансцендентална дисциплина. Ова значи дека нејзините описи се одвиваат согласно начелото на „два чекора напред, три чекора назад“, движејќи се помеѓу она кое условува едно нешто и она кое е обусловено од него. Поинаку речено, одредбите на она кое сочинува дадено нешто мора постојано да се ревидираат земајќи ги предвид одредбите на она кое е сочинето од него, што пак вродува со збогатување на одредбите на ова второто, па одново на првото - и така натаму до бескрај. Како што ќе биде востановено, ова е само една од сличностите меѓу начинот на кој Кјеркегор ја води својата расправа и оној за прв пат тематизиран од Хусерл. Впрочем, тие повлекуваат и еден подлабок паралелизам во основните поставки на обајцата.

${ }^{6}$ Се чини дека во Поимот на тегобноста па и пошироко, Кјеркегор се служи со термините „актуално“ или „реално“ [virkelig] и „идеално“ на начин кој е помалку „тематски“ одошто е „оперативен“. Нивното значење се менува согласно контекстот во кој се среќаваат и нешта- 
препреки. Од една страна, една вака устроена етика, доколку се задржи во рамките на она што Кјеркегор го именува „прва етика“"7 - поточно, на етиката која потсетува на онаа од Или-или и од Страв и треперење ${ }^{8}$, каде „етичкото“ е сведено на животен стадиум или на некаков вид на Weltanschauung, на светоглед - го поставува идеалното како цел за човекот, без да може да му ги понуди актуалните средства со кои тој би можел да го оствари; пострашно: без воопшто и да се осигура дека тој навистина ги поседува. Токму затоа, соочена со она што отклонува од ваквата цел, значи: исправена пред направениот грев, таа има потреба да се оддаде на укорување и на евентуална казна, но истовремено се растројува пред еден, за почеток, одделен чин, кој ѝ е несфатлив во неговата ненадејност ${ }^{9}$. За да се справи со него, етиката би морала да се откаже од нејзината усмереност која поаѓа од идеалното за да го достигне актуалното, да го напушти наметнувањето на ова првото врз ова второто и да се сврти кон индивидуалниот грев кој, како непредвиден и непредвидлив настан, треба да стане нејзина нова почетна точка. Таа би морала, со други зборови, да се престори во една „втора етика“ или, како што Кјеркегор уште и ја нарекува - во една „христијанска етика“. Но, од друга страна, етиката, без оглед на тоа дали станува збор за онаа првата или за оваа втората, е неспособна да го издигне актуалното на ниво на идеалното, поточно, што се однесува до првата - да го сочини образецот на непогрешливоста врз основа на бројни безгрешни дејствувања; а што се однесува до втората - да ја произведе можноста за грешење тргнувајќи од мноштво различни гревови. Така, ако најголемиот недостаток на првата етика е нејзината некадарност да го прифати сознанието дека да-

та на кои им се припишуваат. По оваа точка, види: Paul L. Holmer, On Kierkegaard and the truth, Eugene: Cascade Books, coll. Paul L. Holmer Papers, 2012, pp. 172-173

Така на пример, „идеално“ напати означува нешто што претставува онтолошко-гносеолошки архетип, напати нешто што претставува практичен идеал, а честопати - како што е случајот овде - и двете наеднаш.

${ }^{7}$ CA (en), op. cit., p. 20; BA, op. cit., SS. 16-17; CA (fr), op. cit., p. 177

${ }^{8}$ Кјеркегор и самиот се повикува на она што неговиот псевдоним, Johannes de Silentio или „Јоханес од Тишината“, го изнесол во Страв и Треперење. Згора на ова, вакво е и видувањето на неколку негови толкувачи. По оваа точка, види, на пример: Arne Grøn, The concept of anxiety in Søren Kierkegaard, tran. Jeanette B. L. Knox, Macon: Mercer University Press, 2008, pp. 133-144 и Claudia Weltz, Keeping the secret of subjectivity: Kierkegaard and Levinas on conscience, love and the limits of self-understanding in Karl Verstrynge, Claudia Welz (ed.), Despite oneself: subjectivity and its secret in Kierkegaard and Levinas, London: Turnshare Itd., 2008, pp. 192-194

${ }^{9}$ Во оваа смисла, кјеркегоровата тукашна „прва етика“ приликува и на етиката на Кант, барем на онаа елаборирана во Основа на метафизиката на моралот. За него, со оглед на тоа дека волјата која бира зло е всушност волја детерминирана од природните склоности и нагони, т.е., со оглед на тоа дека таа е недостаток од волја, злото би било помалку предмет на некаква етика, одошто, на пример, на физиката или на биологијата. Работите сепак стојат поинаку во Религијата во границите на самиот ум. За споредба на кјеркегоровиот и кантовиот третман на прашањето на злото, види: David Roberts, Kierkegaard's analysis of radical evil, London/New York: Continuum, coll. Continuum Studies in Philosophy, 2006 
ден човек згрешил, најголемата мана на втората е нејзината некадарност да разбере дека тој, било како единка или како род, е воопшто способен да греши.

Како тогаш оваа слабост би можела да се надомести? Не, тврди Кјеркегор, преку самата етика, а преку втората спомената наука, догматиката, која спротивно на етиката тежнее кон возвишување на актуалното на степен на идеалното. Имено, догматиката ѝ доаѓ напомош на етиката, а поточно, на втората етика, обезбедувајќи ѝ го она кое таа не може да го постави, а со кое мора да се служи: „идеалната можност на гревот“, која Кјеркегор за почеток лабаво ја определува уште како peccatum originale ${ }^{10}$. Така, благодарение на догматиката, втората етика станува способна да го направи исчекорот од нејзиното појдовно место, од одделниот грев, кон поединечната и заедничка можност за грешење.

Сега, самата потреба од ваков двоен пристап кон прашањето на гревот, односно, од негово определување и како идеалност и како актуалното, односно, доколку претпочитате, и во неговата можност и во неговата фактуалност или фактичност, веќе упатува на тоа дека, со зборовите на Кјеркегор, епистемолошката атмосфера ${ }^{11}$ во која гревот би требало да биде обработен е, во најшироката смисла на зборот, една трансцендентална атмосфера. Па и покрај ова, втората етика и догматиката, со дадените гревови и нивната идеалната можност, изворниот грев, не се доволни за да ја заокружат ваквата трансцендентална атмосфера. Ова е така бидејќи и покрај тоа што догматиката ѝ го обезбедува на втората етика овој рессаtum originale, самата таа не може да го објасни преку неговото потекло. Следствено, таа мора да се задоволи со претпоставката дека тој навистина, на еден или на друг начин, нужно произлегува од природата на човекот и оттаму, дека тој навистина е онаков каков што е. Поинаку речено: догматиката, останувајќи доследна на нејзината суштина, надлежност и ограничувања, мора да постапува со изворниот грев како со една од нејзините догми.

Но, доколку претходните две науки го распределуваат доменот на гревот без трансцендентално да го исцрпат, тогаш како третата наука, психологијата, би можела да придонесе кон неговото потполно обработување? Со кој аспект на гревот се занимава психологијата? Одново, слично како како и догматиката, а за разлика од втората етика, таа се занимава со една врста на можност, со она која Кјеркегор ја именува „реалната можност на гревот“:

10 Терминот peccatum originale ќ биде, во рамките на овој труд, или оставен на латински јазик, или преведен со буквалното „изворен грев“ - наместо со „прародителски“ или „првороден грев“. Причината позади ваквиот избор лежи во тоа што Кјеркегор изречито ја отфрла разликата помеѓу некаква „идеална можност на гревот“, разбрана како изворен грев од една страна и првородениот грев од друга. Напротив, а како што ќе биде посочено, повикувајќи се на источните отци, тој го изедначува изворниот грев со првородениот, што пак се одрази на одликите на особениот вид на трансцендентализам кој тој го практикува. Се разбира, без едно вакво разграничување, Кјеркегеровите забелешки и решение - како и сето она кое тие го повлекуваат - би останале, барем текстуално: незабележливи.

11 „За секоја вистина на поим“, повторува на неколку наврати Кјеркегор, „има вистина на атмосфера“, на „расположба“, на... Stimmung. По оваа точка, види: CA (en), op. cit., pp. 1415; BA, op. cit., SS. 10-11; CA (fr), op. cit., pp. 170-171 
Но овој останок од каде постојано навира гревот - не со нужност (бидејќи едно нужно раѓање е состојба, како што на пример целата историја на растението е една ваква состојба), а со слобода - овој останок, оваа предиспонирачка претпоставка, реалната можност на гревот, е предмет на интерес на психологијата. ${ }^{12}$

Се разбира, по сето она што беше изнесено за идеалното и за актуалното или за можноста и нејзината противтежа, да се зборува за такво нешто како „реалната можност на гревот“, која Кјеркегор за почеток ја определува само како некаква предиспозиција - а понатаму и како тегобност - се чини потполно противречно. Во најмала рака, оваа синтагма опасно приликува на една од оние Хегелијански посредства [Vermittlung] - оние помирувачки фактори вметнати меѓу две спротивности со цел да го олеснат преминувањето од едната кон другата - а на кои, како што е добропознато, Кјеркегор не престанува да се навраќа со една нему својствена, деликатна мешавина од подбив и примедба ${ }^{13}$. Сепак, ваквиот приговор не е издржан, ако ништо друго тогаш заради тоа што положбата на психологијата во севкупното знаење за гревот - и онаа на нејзиниот предмет, реалната можност на гревот, во поглед на предметите на двете други науки - е многу посложена од една проста „меѓуигра“. Споредувајќи ја психологијата со догматиката и со втората етика од една страна и реалната можност на гревот со неговите идеална можност и актуалност од друга, Кјеркегор пишува:

Ако некој праша поточно како и до каде психологијата го проследува набљудувањето на својот предмет, очигледно е по себе а и од она што претходи дека секое набљудување на актуалноста на гревот нема врска со неа, и дека како набљудување не ѝ припаѓa [ниту] на етиката со оглед на тоа дека етиката никогаш не е набљудувач, а секогаш обвинува, суди, дејствува $[\ldots]$ Како што психологијата длабоко се нурнува во можноста на гревот, таа незнаејќи ѝ служи на една друга наука која само чека таа да заврши за самата да започне и да ѝ помогне во објаснувањето. Оваа друга наука не е етиката, бидејќ и етиката нема ама баш ништо со ваквата можност. Напротив, се работи за догматиката, и овде одново се јавува проблемот на изворниот грев. Додека психологијата продира во реалната можност на гревот, догматиката го објаснува изворниот грев, кој е неговата идеална можност. Наспроти ова, втората етика нема ништо ниту со можноста на гревот, ниту со изворниот грев. ${ }^{14}$

\footnotetext{
${ }^{12} C A(e n)$, op. cit., p. $21 ; B A$, op. cit., S. 18; CA (fr), op. cit., p. 178

13 Така, на пример, уште во воведот: „Посредството е двосмислено, бидејќи посочува истовремено на врската меѓу двете [нешта] и на резултатот на врската, она во кое двете се врзуваат едно со друго и двете [нешта] кои се врзале едно со друго, односно едновремено единството на односот и двата елементи кои биле во врска еден со друг. Тоа упатува на движење, како и на мирување. Дали ова е совршенство, мора да се определи подлежувајќ́ го посредството на поподробно дијалектичко испитување, за жал, сѐ уште се чека на него.“, $C A$ (en), op. cit., p. 11; BA, op. cit., SS. 7-8; CA (fr), op. cit., pp. 167-168

${ }^{14} C A$ (en), op. cit., pp. 22-23; BA, op. cit., SS. 18-19; CA (fr), op. cit., pp. 179-180
} 
Тргнувајќи од она што Кјеркегор го вели овде, се чини дека психологијата и реалната можност на гревот играат, всушност, една двојна и навидум противречна улога. Од една страна, а според она што стои при крајот на овој извадок, догматиката се осврнува на идеалната можност на гревот, вклучително, и на оној на кој се сосредоточува психологијата, на гревот во неговата реална можност. Одовде, изгледа дека на епистемолошки план, догматиката ѝ претходи на психологијата, а изворниот грев ја условува предиспозицијата за грешење, односно тегобноста ${ }^{15}$. Но, од друга страна, а согласно на она што стои на почетокот, догматиката започнува да го рассветлува гревот како идеална можност само откако психологијата ќе заврши со нејзиното разјаснување на гревот како реална можност. Оттаму, изгледа дека, обратно, психологијата е онаа која има предимство во однос на догматиката, а предиспозицијата за грешење, тегобноста, е онаа која го овозможува изворниот грев. На која наука тогаш треба да ѝ се даде предност во испитувањето на гревот? И, многу поважно: што е овде услов за возможност, а што она кое е обусловено од него?

Во извесна смисла на зборот, може да се рече: и двете. Ова зависи од тоа за кој, или подобро, за чиј грев станува збор. Доколку се работи за кој било грев на даден човек од историјата на човештвото, тогаш догматиката и нејзината идеална можност стапуваат на должност пред психологијата со нејзината реална можност. Но, доколку се работи за peccatum originale - и воколку истиот е протолкуван на начинот кој, како што ќе увидиме, Кјеркегор го толкува, односно како еден одделен грев на еден особен човек - тогаш обратно, психологијата и реалната можност стапуваат на должност пред догматиката и идеалната можност на гревот.

Конечно, а од една страна, тоа што психологијата може да ѝ претходи на догматиката, а реалната можност на гревот да ја обусловува неговата идеална можност, ја запечатува севкупната трансцендентална атмосфера на овој, но и ја надополнува. Впрочем, ваквиот капацитет на психологијата и на реалната можност на гревот се потврдува и со изјавите според кои таа „се занимава со тоа како гре-

\footnotetext{
${ }^{15}$ И покрај тоа што во овој случај, психологијата и реалната можност на гревот навистина се чинат поместени помеѓу догматиката и идеалната можност од една страна, и етиката и актуалноста од друга, тие сепак не претставуваат некакво Хегелијанско посредување меѓу овие. Ова се должи на тоа што, според објаснувањата на Насон, Кјеркегор гледа на спротивставувањето на две нешта, било да се од логички, онтолошки или некој друг вид, како на противречење. За разлика од него Хегел ги претопува сите спротивности во потесната категорија на релативни спротивности. Доследно, тој ги прави зависни едни од други, но и го допушта нивното истовремено важење во поглед на едно и исто нешто - макар за тоа била потребна некаква медијација. Одовде, психологијата и реалната можност на гревот не би можеле да претставуваат премин меѓу догматиката со неговата идеална можност и етиката со неговата актуалност, бидејќи тие се толку антиподни на етиката и на актуалноста, што и самите би имале потреба од некаков начин на премостување на јазот кој ги двои. Токму затоа разликите меѓу нив не можат да се совладаат така што ќе се надминат, а така што ќе се „прескокнат“. По оваа точка, види: Shannon Nason, „Opposites, contradictories and mediation in Kierkegaard's critique of Hegel“, The Heythrop journal 53 (2012)
} 
вот може да настане, не со тоа дека настанал“16; таа не се осврнува на детали на „емпириски начин“17. Од друга страна, земајќи предвид дека „психологијата е наука за субјективниот дух“18 - и напоредно, дека реалната можност на гревот е субјективна можност - трансцендентална атмосфера на гревот се стекнува со една субјективна димензија. Така, психологијата ќе ѝ даде поддршка на догматиката и посредно, и на втората етика на сличен начин како што догматиката ја беше поткрепила втората етиката, поточно снабдувајќ ја, преку тегобноста, со објаснување за потеклото на изворниот грев на ниво на индивидуата ${ }^{19}$.

Поимот за тегобноста, споменавме, е дело чиј првичен предмет не е толку тегобноста колку што е гревот - и ова е секако вистина, но не е и целата вистина. Имено, во него Кјеркегор го истражува гревот воопшто задржувајќи се на еден парадигматичен грев, посебен поради неговата положба во поглед на сите останати: првиот грев на првиот човек, Адам. А пак, како што беше наговестено, спротивставувајќ се на добар дел од западната философија - значи, колку на римокатолицизмот, толку и на протестантизмот - Кјеркегор се повикува на „грчката црква“20 и ја изедначува идеалната можност на гревот, изворниот грев, со

${ }^{16}$ CA (en), op. cit., pp. 21-22; BA, op. cit., S. 18; CA (fr), op. cit., p. 178

${ }^{17}$ CA (en), op. cit., p. 22; BA, op. cit., S. 19; CA (fr), op. cit., p. 179

Патем речено, одовде произлегува дека Шестов, вообичаено внимателен читател на Кјеркегор, прави нечуен превид кога напоменува дека тегобноста е „причина изворниот грев, причина за падот на човекот“. Едно вакво невнимателно толкување го води Шестов до погрешната увереност дека Кјеркегор сепак се оддал на умување согласно „нужноста“ кое би морал да го отфрли во име на верата во апсурдното - како и до заклучокот дека неговата списа би била подоследна кога тој би се придржувал до библиското слово на подословен начин. Спротивно на овие убедувања, очигледно е дека доколку исто како догматиката, психологијата е наука од идеалистичко-трансцендентална врста, тогаш нејзиниот предмет, реалната можност на гревот или тегобноста не е причина за гревот, туку негов услов за возможност и оттаму, не претставува никаква „нужност“. По оваа точка, види: Léon Chestov, Kierkegaard et la Philosophie Existentielle Vox Clamantis in Deserto, Paris : Vrin, coll. Bibliothèque d'Histoire de la Philosophie, 2006, p. 131

${ }^{18}$ CA (en), op. cit., p. 23; BA, op. cit., S. 20; CA (fr), op. cit., p. 180

19 Тргнувајќи од ова, воопшто не зачудува тоа што еден Хајдегер, кој воглавно ретко се повикува на мислителите на кои им е најмногу должен - a, кога еднаш ќ се осуди на таков чекор, тоа го прави со огромна доза на критичност - отфрла добар дел од анализите на Кјеркегор, но отворено ги прифаќа гореспоменатите. Имено, тој забележува дека сите философски дела на Кјеркегор се задржуваат на егзистенциелната [existenziell] димензија на човекот, наместо да се свртат кон егзистенцијалната [existenzial], значи, се усмеруваат на постоењето за сметка на устројството на ваквото постоење, но и додава: „со исклучок на неговиот оглед за поимот за тегобноста“. По оваа точка, види: Martin Heidegger, Sein und Zeit. Elfte unveränderte Auflage, Tübingen: Max Niemeyer Verlag, 1963, S. 235

${ }^{20} C A$ (en), op. cit., p. 26; BA, op. cit., S. 22; CA (fr), op. cit., p. 185

Се разбира, Кјеркегор жали што овој православен начин на поимање на гревот не е ништо повеќе од „етикета“ која нема подлабока конщептуална тежина, но сепак, од сите оние кои накратко ги напоменува, тој е најблиску до оној на кој и самиот ќе се задржи. Така: „Оттаму, да се објасни [гревот на Адам] значи да се објасни изворниот грев, и едно об- 
$\pi \alpha \tau o ́ \rho \imath к о v ~ \dot{\alpha} \mu \alpha ́ \rho \tau \eta \mu \alpha$, значи со овој прародителски или првороден грев. А пак, согласно претходно изложените епистемолошки поставки, земјаќи предвид дека изворниот грев не е ништо друго од идеалната можност на гревот, и со оглед на тоа дека тој претставува индивидуален грев, макар бил и првиот, во овој единствен случај, идеалната можност на гревот и одреден поединечен грев стануваат едно. Способноста на секој еден човек, вклучително и на Адам - како и онаа на човековиот род во целост - да греши е изедначена со грешката на човекот Адам. Во спротивно, толкувањето на овој грев би се соочило со еден од два нерешливи проблеми: или гревот на Адам би иे претходел на способноста да се греши, во којшто случај гревот би приликувал на некаков вид на пренеслива болест, а идеалистичко-трансценденталната рамка на анализата би била неповратно извитоперена; или, тој би ѝ следел на способноста да се греши, во којшто случај, ваквата рамка би била бездруго запазена, но, појаснува Кјеркегор, Адам би се нашол надвор од историјата на грешното човештво, и згора на тоа, би бил единствениот човек кој би бил изземен од спасение. Поинаку речено, условот за возможност се изедначува со едно од фактуалните или фактичките нешта во чија основа би требал да лежи, или, според библиската реч која Кјеркегор честопати ја повторува, „гревот“ - читајте: грешноста - „влегол на светот преку грев “21. Секако, истото важи и за самиот Адам, кој мора едновремено да биде татко на човештвото, и еден од луѓето кои потпаѓаат под него, да биде првиот човек меѓу луѓето. Со други зборови, кога Кјеркегор настојува на тоа дека „првиот грев значи нешто друго од еден грев (т.е., еден грев како многу други), нешто друго од еден грев (т.е., бр. 1 во однос на бр. 2)“622; и паралелно, дека Адам не претставува само нумерички првенец на родот, она кое тој го има на ум е дека во овие случаи prius едновремено значи и a priori.

Но пак, зарем ваквото видување на гревот на Адам не ги побркува условите со причините, можностите со фактичноста или фактуалноста? Зарем тоа не ја „загадува“ трансцендентална атмосфера на гревот? Голем број на постари и современи мислители од идеалистичката или трансценденталната традиција - Платон и Кант, се разбира, но и некој како Хајдегер или Анри - би одговориле потврдно $^{23}$. Сепак, постојат и такви чие учење може напротив да се разбере токму на овој начин. Таков е случајот со Хусерловата феноменологија, воколку истата е окарактеризирана како трансцендентален емпиризам.

јаснување кое го објаснува Адам но не и изворниот грев, или изворниот грев но не и Адам не е од никаква помош.“, $C A$ (en), op. cit., p. 28; BA, op. cit., S. 24; $C A$ (fr), op. cit., p. 186

${ }^{21} C A$ (en), op. cit., p. 32; BA, op. cit., S. 28; $C A$ (fr), op. cit., p. 190

${ }^{22} C A$ (en), op. cit., p. 30; BA, op. cit., S. 26; CA (fr), op. cit., p. 188

${ }^{23}$ Веќе Платон во својот Софист се шегува со оние кои се обидуваат да го објаснат битие-

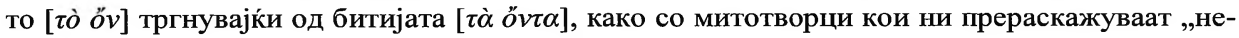
какви приказни, како да сме мали деца“. И се чини дека по овој основ, во двете столетија меѓу оваа Платонова закачка насочена против претсократовците и Анриовото „археологијата секако не е генеалогија“ упатено на Фуко, идеализмот, од која и да е поконкретна врста, останал безмалку непроменет. По оваа точка, види: Платон, Софист, прев. Ивица Весов, Скопје: Аз Буки, 2008, 242b-243с и Michel Henry, Généalogie de la psychanalyse, Paris: PUF, coll. Epiméthée, 1983, p. 14 
Во која смисла на зборот може да се зборува за Хусерловата феноменологија како за трансцендентален емпиризам? Споредувајќ ја оваа со учењето на Делез - кој и самиот реферира на сопствените стојалишта како на трансценденталноемпиристички - Депра воочува две значења на оваа, навидум парадоксална синтагма. Додека првото се однесува на потребата од генеза на трансценденталната свест преку нејзините пасивни синтези, поточно, од продирње до нејзината елементарна граѓa и до временската структурираност на истата; второто се однесува на нужноста трансценденталната свест да биде, статички или генетички, и самата дадена во искуството, во едно трансцендентално искуство ${ }^{24}$. Иако и двете вакви значења би можеле да бидат релевантни за сопоставувањето на Кјеркегор со Хусерл $^{25}$, постои и трето значење апликабилно на обајцата, она посочено од Рикер. Според него, за феноменологијата на Хусерл трансценденталниот емпиризам претставува опасноста во која би западнала доколку по нејзината прва трансцендентална редукција не продолжи со втора, еидетичка редукција, односно, со сведување на фактумот на $\varepsilon \tilde{i} \delta o \varsigma$, на неговата идеална суштина ${ }^{26}$. Но, она на кое Рикер овде се задржува како на тешкотија која би морала да биде надмината е токму она кое во еден од своите манускрипти Хусерл го претполага: еден трансцендентален домен кој е и самиот фактум, еден трансцендентален фактум. Тој вели:

Овде имаме еден случај кој е необичен и единствен, имено, за односот меѓу фактум и еидос. Битието на еден еидос, битието на еидетичките можности и универзумот на овие можности е ослободен од бивањето и небивањето на кое било остварување на таквите можности, тоа е, во поглед на своето бивање, независно од секаква стварност, имено, од онаа која му соодветствува. Но еидосот на трансценденталното јас е незамислив без трансцендентално јас како фактично. ${ }^{27}$

Доследно, првородениот грев - како и самиот Адам - претставуваат, слично на трансценденталното јас на Хусерл, своевидни трансцендентални факти. Но пак, ова значи дека и двете се податливи не само во нивното својство на услови за возможност на останатите факти, туку и преку нивните сопствени услови за возможност, како факти. Поинаку речено, првородениот грев е секако идеална можност на гревот која вродува со индивидуалната и колективна грешност на човекот $^{28}$, но и актуалност која настанува благодарејќи на нејзината реална можност,

\footnotetext{
${ }^{24}$ Nathalie Depraz, «L'empirisme transcendantal : de Deleuze à Husserl », Revue germanique internationale [En ligne], 13 | 2011, mis en ligne le 15 mai 2014, consulté le 10 mai 2016. URL : http://rgi.revues.org/1130

${ }^{25}$ Така на пример, исто како што Кјеркегор го опишува Адамовиот пад како „будење на духот“, Хусерл го објаснува стекнувањето на граѓата со моќ да го возбуди егото како „пра-будење“ [urerwachen] од „црната ноќ“ [Schwarze Nacht].

${ }^{26}$ Paul Ricœur, A l'école de la phénoménologie, Paris : Vrin, 2004, p. 199

${ }^{27}$ Edmund Husserl, Husserliana. Band XV. Zur Phänomenologie der Intersubjektivität. Dritter Teil, den Haag: Martinus Nijhoff, 1973, p. 385

${ }^{28}$ Што не значи, за Кјеркегор, дека и секој прв грев по овој, не вродува со иста таква индивидуална можност. Така: „[Од првиот грев натаму], за ниеден човек не паѓа напамет да се
} 
на тегобноста на Адам. Но, на кој начин тогаш гревот на Адам е овозможен од неговата тегобност?

Со оглед на тоа дека психологијата, си споменуваме, не се осврнуваше на самиот чин на раѓањето на гревот - кому може да му се приближува како на асимптота без никогаш да го стаса - единствениот начин на кој таа може да го расветли овој е појаснувајќи ја расположбата која му претходи и од каде тој произлегува. Во оваа насока, Кјеркегор започнува подвлекувајќи дека Адам е, како и секој човек, спој на тело и душа, но во овој миг, неговите тело и душа сѐ уште не се обединети во неговиот дух, кој е присутен, но спие. Но пак, ваквото амбивалентно присуство на заспаниот дух дејствува како растројувачки фактор. Имено, Адам се наоѓ⿱ во состојба на невиност или уште и на незнаење - односно, на незнаење што е добро, а што зло. Одовде, тој е во неможност да биде слободен, да прави добро или зло. Но истовремено, невиноста и незнаењето во себе кријат и тегобност, славно определена како тегобност пред ништото, значи: како тегобност пред можноста за слободата или „тегобна можност да се може ${ }^{629}$ - да се може да се постапува со добро или со зло. И се разбира, ваквата расположба го привлекува и го одбива Адам, го заведува и го плаши. Па и покрај ова, таа не е, самата по себе, доволна за да го овозможи неговиот пад. Освен неа, вели Кјеркегор, потребно е и нешто друго:

[Овде], сѐ уште има невиност, но доволен е еден збор за незнаењето да се сконцентрира. Природно, невиноста не може да го разбере овој збор, но тегобноста како да го доби првиот плен; наместо ништото, таа сега има енигматичен збор. Така, кога во Битие се изјавува дека Бог му рекол на Адам „од дрвото за познавање на доброто и на злото не јади“, само по себе е разбирливо дека во стварност, Адам не го разбрал овој збор; бидејќи, како можел да ја разбере разликата на доброто и на злото, кога таа ќе произлезе од уживањето во плодот ${ }^{30}$

Се разбира, толкувањата според кои Божјата забрана е не само conditio sine qua non на Адамовиот грев, туку и на еден или на друг начин го поттикнува овој не се ретки. Нешто пред овој извадок, Кјеркегор и самиот потсетува на едно вакво толкување, она на Леонард Устери, со умерена благонаклонетост. Па сепак, тој во крајна линија ги отфрла ова и нему сличните читања, и ги заменува со две свои оригинални согледби. Од една страна, за него, она што покрај тегобноста е потребно за Адамовиот скок во гревот - а кое се состои во едно буквално salto mortale - е помалку смисловната содржина на забраната која за Адам, е потполно загадочна, одошто самата нејзина реч, самиот, така да се рече, говорен чин. Истото важи и за судот кој ја предвидува последователната казна „сигурно ќе ум-

рече дека со неговиот прв грев грешноста влегла во светот, па сепак, таа влегува во него преку овој човек на сличен начин (т.е., на начин кој не е суштински различен [од овој]) [...]", CA (en), op. cit., p. 33; BA, op. cit., S. 29; $C A$ (fr), op. cit., pp. 191-192

${ }^{29}$ CA (en), op. cit., p. 44; BA, op. cit., S. 41;CA (fr), op. cit., p. 205

${ }^{30} C A$ (en), op. cit., p. 44; BA, op. cit., S. 41; CA (fr), op. cit., pp. 204-205 
реш“‘31. Но пак, од друга страна, доколку е ова вака, тогаш нејасно е зошто Бог на два наврати би му се обраќал на Адам со слова кои му се неподатливи. Како решение на овој проблем, Кјеркегор предлага:

Овде, во заклучокот се држев до библискиот расказ и претпоставив дека забраната и гласот на казната доаѓаат однадвор. Природно, ова е нешто кое измачувало многу мислители, иако тешкотијата е поправо за насмевка. Невиноста навистина може да зборува, воколку во јазикот поседува израз за сѐ што е духовно. Соодветно, доволно е да си претпоставиме дека Адам си зборувал со себеси. Така се отстранува ова несовршенство на расказот според кое некој друг му зборувал на Адам за тоа кое овој не го разбирал. Но, од тоа што Адам можел да зборува не следи дека умеел и да го разбере во подлабока смисла она што се кажало. ${ }^{32}$

Одовде, се чини дека во невиноста и нејзиниот „мир и починка““33, освен состојбата на тегобност, потребно е да продре и некаква реч, или поправо, две корелативни речи: онаа на забраната и онаа на казната, кои Адам си ги упатува самиот на себе. Поинаку речено, прародителскиот грев, покрај тегобност, изискува

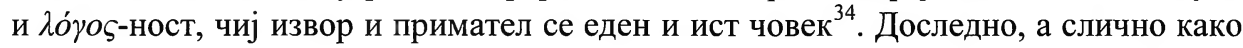
и за Бог, Кјеркегор тврди дека во поглед на змијата не може да си сочини некоја „определена идеја“ и дека тешкотијата во овој приказ се состои во тоа дека соблазната дога́а однадвор ${ }^{35}$.

Но пак, понатаму, тоа што првородениот грев е говорен однос на Адам со него самиот значи и дека тој се одвива надвор од врската со каква било другост, било да се работи за онаа на Бог, или за онаа на змијата ${ }^{36}$. Се разбира, нејзината подлога е, така да се рече, „веќе отсекогаш“ дадена: Адам е едновремено спој на душа и тело и заспан дух, тој е подвоен меѓу сопствената невиност и антиципираната грешност, меѓу можноста да може и стварното можење, онакво какво го проектира надвор од себе. Па и покрај ова, само кога гревот еднаш ќе биде направен, само по неговото извршување, ова двојство ретроактивно се реализира како спро-

31 „По зборот на забраната следи зборот на судот: „сигурно ке умреш“. Што значи тоа да се умре, Адам, природно, не знае [...]“, CA (en), op. cit., p. 45; BA, op. cit., S. 41; CA (fr), op. cit., p. 205

${ }^{32} C A$ (en), op. cit., p. 45; BA, op. cit., S. 42; CA (fr), op. cit., p. 206

${ }^{33} C A$ (en), op. cit., p. $41 ; B A$, op. cit., S. 38; $C A$ (fr), op. cit., p. 201

${ }^{34}$ Можеби ова е причината поради која, уште во воведот на својата списа, Кјеркегор порачува дека гревот е предмет на проповед каде „индивидуата, како индивидуа, се обраќа на индивидуата“. Доколку гревот се остварува зборувајќи, не изненадува тоа што тој единствено може да се прости зборувајќк. По оваа точка, види: CA (en), op. cit., p. 16; BA, op. cit., S. $12 ; C A$ (fr), op. cit., p. 172

${ }^{35}$ CA (en), op. cit., p. 48; BA, op. cit., S. 44; CA (fr), op. cit., p. 208

${ }^{36}$ Што се однесува пак до Ева, таа и онака е „изведено битие.“ По оваа точка, види: $C A$ (en), op. cit., p. 47; BA, op. cit., S. 44; CA (fr), op. cit., p. 208 
тивставеност ${ }^{37}$ и притоа го овозможува воспоставувањето на опозицијата меѓу човекот и другоста, значи: Бог, сатаната и останатите луѓе.

Конечно, а со самото тоа што прародителскиот грев едновремено ја преставува идеалната можност на гревот, капацитетот за грешење на секој еден човек - вклучително и на Адам, и одреден поединечен грев - грешката на човекот Адам; со, самото тоа што, дополнително, ваквиот грев, како резултат на дијалектиката меѓу забраната и казната му се случува на Адам во неговиот однос со самиот себеси и она што допрва ќе го стане, а не во однос на другоста; и доколку, етиката е, како што тврдеше Кјеркегор, „обвинител, судија, дејствител“- ваквиот грев не е, во строга смисла на зборот: етичка категорија. Тој е една мета-етичка, поправо, една пра- или пред-етичка категорија. Имено, ако невиноста и незнаењето се одликуваат со неразликување на доброто и злото, поточно со „тегобна можност да се може“ да се прави добро и зло; ако овие во мигот на гревот се преобразуваат во способност за распознавање на доброто и на злото, или стварност на можноста да се постапува согласно на едното или на другото, тогаш гревот кој за прв пат ја открива оваа разнородност, самото остварување на можноста за избор не е ниту добра ниту зла. Таа е „отаде“. И токму затоа зборувајќи човек може да се искупи за сите свои останати гревови, но ниту едно покајание и следствено - никаква прошка не може да му ги врати, како на човек, еднаш загубените невиност и незнаење, неговата бесмртност. Скокот „наназад“ едноставно не достига дотаму. Оттаму, спасението на Адам и она на секој еден човек човек - воколку гревот на Адам е, си споменуваме, аналоген на првиот грев на секој човек во тоа што преку нив гревот влегува во светот - мора ем да дојде на поинаков начин, ем да не го допире човекот во неговата потполност, како душа и како тело.

Се разбира, самиот Кјеркегор не оди дотаму, барем не на изречит начин. Но тој на неколку наврати иронично се навраќа на сите учења, а особено оние од протестантска инспирација, кои наместо да го објаснат првородениот грев, се оддаваат на што е можно поостро морализирање на истиот. Тие се обземени од „чувство на побожност (со етички тоналитет)“ кое се одликува со „една безмалку женска срдба“, со „фанатизмот на вљубена девојка““38, поточно, запаѓаат во „сентименталност или духовитост“, „меланхолија или лежерност“, но „без да ја сфатат етичката поента“"39. Со зборовите на Кант, тие се совладани не од полетен ентузијазам, а од многу поопасното - Schwärmerei.

Според сето ова, а што се однесува барем до Кјеркегоровото сфаќање на првородениот грев, Тартиф, се чини, сепак бил во право. Ниту гревот може да се

${ }^{37}$ Така, на пример: „За разлика од непосредноста, невиноста не е нешто кое мора да биде надвишено, нешто чие качество треба да биде надвишено, нешто што во суштина не постои, туку е нешто кое бивајќи надвишено и како последица на надвишувањето за прв пат настанува како нештото кое тоа било пред да биде надвишено и кое е сега е надвишено.“, CA (en), op. cit., p. 36-37; BA, op. cit., S. 33; CA (fr), op. cit., p. 196

${ }^{38}$ CA (en), op. cit., p. 26; BA, op. cit., S. 22; CA (fr), op. cit., p. 184

${ }^{39}$ CA (en), op. cit., p. 36; BA, op. cit., S. 32; CA (fr), op. cit., p. 195 
јави во тишина, без да биде изустен збор; ниту пак, напоредно, престапот може да биде престап надвор од скандалот на светот. Имено, гревот на Адам не е толку престап колку она што за прв пат ја отвора можноста за престап и другоста, што значи дека тој истовремено овозможува другите да западнат во престап, и да судат за секој еден престап. Она кое за прв пат го сочинува скандалот и светот не е скандал во светот, а скандал на светот - во смисла на она кое го обусловува секој иден скандал на кој светот ќе подлегне; и скандал на светот - во смисла на она кое притоа го оспособува, дури и ретроактивно, да се „скандализира“. 


\section{Литература}

Молиер. Тартиф. прев. Лазо Каровски. Скопје: Детска Радост, 1996.

Платон. Софист. прев. Ивица Весов. Скопје: Аз Буки, 2008.

Свето евангелие според Матеја. Свето Писмо (Библија). Скопје: Македонска книга, 1991.

Chestov, Léon. Kierkegaard et la Philosophie Existentielle Vox Clamantis in Deserto. Paris : Vrin, coll. Bibliothèque d'Histoire de la Philosophie, 2006.

Depraz, Nathalie. «L'empirisme transcendantal : de Deleuze à Husserl ». Revue germanique internationale [En ligne], $13 \mid 2011$, mis en ligne le 15 mai 2014, consulté le 10 mai 2016. URL : http://rgi.revues.org/1130.

Grøn, Arne. The concept of anxiety in Søren Kierkegaard. tran. Jeanette B. L. Knox. Macon: Mercer University Press, 2008.

Heidegger, Martin. Sein und Zeit. Elfte unveränderte Auflage. Tübingen: Max Niemeyer Verlag, 1963.

Henry, Michel. Généalogie de la psychanalyse. Paris : PUF, coll. Epiméthée, 1983.

Holmer, Paul L. On Kierkegaard and the truth. Eugene: Cascade Books, coll. Paul L. Holmer Papers, 2012.

Husserl, Edmund. Husserliana. Band XV. Zur Phänomenologie der Intersubjektivität. Dritter Teil. den Haag: Martinus Nijhoff, 1973.

Kierkegaard, Sœren. The Concept of anxiety. tran. Reidar Thomte and Albert B. Anderson. Princeton: Princeton University Press, 1980.

---. Miettes philosophiques. Le concept de l'angoisse. Traité du désespoir. trad. Knud Ferlov et Jean-Jacques Gateau. Paris : Gallimard, coll. Tel, 1990.

Molière. Le Tartuffe ou l'imposteur. Paris : Hachette, 1992.

Nason, Shannon. „Opposites, contradictories and mediation in Kierkegaard's critique of Hegel". The Heythrop journal 53 (2012) : 24-36.

Ricœur, Paul. A l'école de la phénoménologie. Paris : Vrin, 2004.

Roberts, David. Kierkegaard's analysis of radical evil. London/New York: Continuum, coll. Continuum Studies in Philosophy, 2006.

Schrempf, Christoph, hrsg. Zur Psychologie der Sünde, der Bekehrung und des Glaubens. Leipzig: Fr Richter, 1890.

Verstrynge, Karl and Claudia Welz, ed. Despite oneself: subjectivity and its secret in Kierkegaard and Levinas. London: Turnshare ltd., 2008. 
Vera HADZI-PULJA

\section{ON SIN, SILENCE AND OTHERNESS}

A transcendental reading of Kierkegaard's teaching on original sin

\section{Summary}

This paper will attempt to explore the connection between sin and silence, as well as the one between sin and worldhood, i.e. otherness, by examening Kierkegaard's doctrine of sin - and, more specifically, Adam's first sin - in The concept of anxiety. It will pursue three interconnected goals. Its first goal is to point out that Kierkegaard's work puts forth a genuine epistemological framework, which is both idealistic and transcendental. Its second goal will be to show that the fulfillment of Adam's sin requires speech, that is, a peculiar kind of dialogue of man with himself; and, at the same time, that such a fulfillment can only take place outside of any relationship with the other. Indeed, Adam's original sin is what first establishes all kinds of otherness. Finally, on the basis of previously attained conclusions, its third goal is to demonstrate that the subsuming of original sin under the class of ethical concepts, its characterisation as good or evil, is, at the very least, to be taken cum grano salis.

Keywords: KIERKEGAARD, ANXIETY, ORIGINAL SIN 